\title{
The Global Unions and Global Governance: Analysing the Dialogue between the International Trade Union Organizations and the International Financial Institutions
}

Rueckert, Y.

University of Portsmouth, UK

\section{$\underline{\text { Abstract }}$}

The article examines the dialogue between the Global Unions, the World Bank and the International Monetary Fund which was formalized in 2002 and was originally initiated by the Global Unions. The dialogue takes place at three levels: headquarters; sector; and countrylevel. The Global Unions try to use the dialogue to persuade the International Financial Institutions to change their policies to promote and integrate a stronger social component within the system of global governance. The article focuses on the headquarters-level dialogue and examines some of the factors which promote and hinder the success of the dialogue from the perspective of the Global Unions.

\section{$\underline{\text { Keywords }}$}

Global Unions, World Bank, IMF, Global Governance, Dialogue 


\section{The Global Unions and Global Governance: Analysing the Dialogue between the International Trade Union Organizations and the International Financial Institutions}

\section{Introduction}

It has been argued that the existing system of global economic governance undermines worker's rights, worker's conditions and the trade unions that try to defend their interests, with some commentators suggesting that the system needs to be reformed to take labour's interests properly into account (Turner, 2004). Globalization has arguably increased the complexity and interdependencies of actors in employment relations. However, the lack of research suggest that we need more evidence regarding these interaction processes on a global level.

Despite the fact that reports published by the World Bank (WB) and the International Monetary Fund (IMF) argue that countries that have strong trade union and collective bargaining systems tend to have more resilient economies (Aidt and Tzannatos, 2002) and that higher unionization and minimum wages can help reduce inequality (Jaumotte and Buitron, 2015), little attention has been paid to trade unions in the global system of economic governance, in particular their regulatory function and their potential contribution to a more socially orientated system (KochBaumgarten, 2006).

Although it is not widely known, international and national trade union organizations (as recognized actors in global civil society) have since 2002 taken part in a formalized 'dialogue' with the International Financial Institutions (IFIs); that is the World Bank Group and the IMF. This 'dialogue' is an important tool for trade unions as it allows them to raise awareness of organizational representatives in the IFIs regards labour issues. This includes for example the implementation and monitoring of International Labour Organization (ILO) labour standards and a better understanding of the role and importance of collective bargaining as a labour market institution.

This article has two objectives. First, it aims to shed light on this specific type of international policy dialogue which as yet has received no serious attention in the literature. It is argued that the dialogue with the IFIs can be seen as a strategic instrument for the Global Unions to exercise influence over the policy of the IFIs and to shape the rules and institutions of global governance towards a more worker-friendly regime. In this context the article contributes in particular to the literature on transnational unionism and the impact of the Global Unions within global governance. 
The second objective is to present an analysis of some of the factors which promote and hinder the dialogue and its potential as a means to integrate a social dimension into global governance. It is argued that due to its specific characteristics (structure, actors, and frequency of meetings), the dialogue between the Global Unions and the IFIs differs substantially from social dialogue (as defined by the European Union and the ILO) or lobbying. Furthermore, even though the interlocutors of the dialogue are international organizations, they are very different in terms of their organizational characteristics, such as their organizational structures, culture, identity and their resources. These characteristics, which have an impact on the perceptions and decisionmaking of individual organizational representatives are analyzed through the lens of organizational theories. The article does not suggest that the Global Unions are able to revise and reshape the existing democratic deficit in the international policy arena on their own, but that trade unions are important interlocutors and, that the dialogue makes an important contribution in addressing the growing regulatory gap within the global system of governance.

The IFIs are key players in the global governance system. These inter-governmental organizations act as 'agents of global change' and, through their lending to national governments and the conditions they attach to such loans, they have played an important role in governing the international economy since the post-World War II period (Carbone, 2007: 180). In particular the IMF has often attempted to shape the governance of work and employment within nation states by imposing labour related conditions to its loans (Marginson, 2016). By contrast the Global Unions are non-governmental organizations whose members are trade union organizations. They include the International Trade Union Confederation (ITUC), the nine Global Union Federations (GUFs) and the Trade Union Advisory Committee to the OECD (TUAC) (White, 2006).

The dialogue between the Global Unions and the IFIs was formalized in 2002. There had been exchanges of information on a non-regular basis before then, but these exchanges had no formal structure and were often prompted by the potential outcomes of a number of structural adjustment programmes initiated by the IFIs. The main aim of the Global Unions within the dialogue is to persuade the IFIs to commit to a more socially-orientated global policy including the recognition of workers' interests and rights in their development programmes and the conditions attached to their loans. In this context, the integration and consideration of core labour standards in the WB, the International Finance Corporation (IFC) and IMF operations and their implementation has been a major issue for the Global Unions since the beginning of the dialogue. The dialogue takes place at three different levels: the headquarters (HQ)-level, the sector-level and the national-level. The paper focuses on the HQ dialogue as it is not within the scope of this paper to discuss the dialogue at all three levels. The HQ dialogue covers economic 
and social issues concerning workers worldwide as well as the specific policy approaches followed by the IFIs.

\section{Research methods}

The data derives from an on-going qualitative research project based on a combination of semistructured expert interviews, non-participant observation and a content analysis of documentary materials (using QDA-Software (MAX-QDA). The latter includes the minutes of the headquarters-level dialogue, documents relating to the annual meetings of the IFIs and statements and working papers published by the IFIs and the Global Unions. This kind of triangulation allows the researcher to adopt 'different perspectives on an issue under study' (Flick, 2014: 184) and helps to extend the possibilities of knowledge production.

The study is based on a total of 48 semi-structured expert interviews which were conducted between 2008 - 2011 and 2014 - 2017 with representatives from all major international organizations involved in the dialogue. The expert interviews with organizational representatives form the main information basis for paper, providing insights about the organizational culture of the organizations and existing perceptions regards the dialogue and social reality. The problem-centred approach to interviewing offered the possibility to reveal complex mediation processes of action and evaluation patterns around the dialogue, putting the emphasis on the perceptions of the interviewees. A semi-structured interview schedule was used which included no predefined answers.

During the first phase (2008-2011) 32 interviews were conducted with representatives from all major international organizations involved in the dialogue. 18 of these interviews were conducted with senior union officials mainly General Secretaries and Deputy General Secretaries, from the Global Unions Federations (GUFs), the ITUC and the Trade Union Advisory Committee to the OECD (TUAC) as well as the German IG Metall union and the German Trade Union Confederation (Deutsche Gewerkschaftsbund - DGB). Nine interviews were conducted with staff from the WB and the International Finance Corporation (IFC) (including responsible staff for relationships with civil society, economists and procurement specialists) and the IMF (staff from Public Affairs and the Independent Evaluation Office). Five members of staff were also interviewed at the ILO and included advisers on rights at work, specialists on multinational enterprises (MNEs) as well as social policy staff from the ILO office in Washington. The second phase of follow-up interviews between 2014 and 2017 were conducted with staff from the ITUC, the Building and Woodworkers International (BWI), the WB, the IMF and the ILO. 
The interviews were on average between 40 and 60 minutes in length and were conducted at the headquarters of the organisations in Washington D.C., Geneva, London, Brussels and Berlin. In addition, some interviews were carried out during the high-level meetings between the global trade union organizations and the IFIs in 2009 and in 2017 at the IMF both in Washington D.C.. Contacts with interviewees were made directly with the help from the ITUC/Global Unions office in Washington and there was no random selection from an expert register. Some of the contacts came about from respondents who had already been interviewed (snowballing). All of those interviewed have been involved in the dialogue with the IFIs. All interviews have been recorded and transcribed. The author is bilingual and was able to conduct the interviews in German (2 interviews) and English (46).

The data was organized with the help of a QDA-Software (MAX-QDA) and analysed using 'thematic analysis' which is a method for 'identifying, analysing, and interpreting patterns of meaning ('themes') within qualitative data' (Clarke and Braun, 2017: 297). The analysis of the data aimed to reveal the ideas and views of participants which related to the analytical interests of the researcher, in other words the data was analysed with specific questions in mind. After reading through the transcripts several times, initial codes were retrieved from the data. In this context, the analysis focused on the views of individual participants in an attempt to identify commonalities and differences across the organizations which are involved in the dialogue. The software facilitated this process by offering the possibility to colour important text passages and writing notes on the text. The different codes were combined, when possible, into overarching themes whereby some codes were linked to different themes. For example, the theme 'impact of organizational structure' is based on codes referring to 'bureaucracy and democracy', the 'allocation and distribution of competencies', 'internal complexity and contradictions' and 'degree of technocracy'. During this phase the author also took into account the relationship between different codes and themes.

In addition to the interviews, the author was able to observe the high-level meetings in Washington in 2009 and 2017. The author had a formal position as an invited non-participant observer. Conversations during the meetings were followed without any reference to a preprepared schema; this allowed the author to act flexibly and openly within the observation situation. This provided some useful insights into what topics and in which way topics were discussed and, the interactions in the high-level meetings between different actors in the dialogue process. 


\section{Theoretical framework}

The theoretical background of this study is based on the global governance concept and sociological approaches to organization theory. The latter have been chosen for two reasons: firstly, they can help to explain organizational characteristics which have an impact on decisionmaking of organizational representatives and secondly, they can help to strengthen the analytical dimension of the global governance concept.

All global governance concepts emphasize the connection between the process of globalization and the issue of regulation. It has been argued elsewhere that globalization and the growing internationalization of economic activities has impacted negatively on the efficiency of national regulative institutions such as labour laws and collective bargaining (Marginson, 2016). The rising numbers and power of MNEs is arguably a result of the internationalization of production and services, the enhanced mobility of capital and the predominant paradigm of neo-liberal economic policies. Neo-liberal policies have been pursued to a greater extent by many national governments and have arguably led to increased competitive pressure between nation states and transnational companies and to increasing downward pressure on labour standards. In other words, the globalization process has arguably resulted in a 'race to the bottom' (Hepple, 2005: 15; Sengenberger, 2005) with many employers exploiting a reduction in and deregulation of employment rights at the national level, leading to an increase in precarious work low-paid work in many developed countries and, raising considerable challenges for national trade unions (Herod and Aguiar, 2006; Katz and Krueger, 2016).

Although the globalization perspective considers the sovereign nation state to be important (Meyer et al., 2006), challenges such as the 2008 international financial and economic crisis and rising income inequality cannot be overcome at the national level alone. Rather, existing institutions at the national level need to be supported by effective institutional arrangements at the international level. However, it can be argued that in addition to governance and control problems there is a considerable democratic deficit at the heart of the existing global governance system and, through which only a limited spectrum of interests is effectively represented, reflecting existing power asymmetries in the global economy.

Until now the global governance concept has only been weakly specified and as such indicates neither a new theory nor an analytical category (Behrens and Reichwein, 2007). In the broadest sense, global governance can be defined as, 'governing, without sovereign authority, relationships that transcends national frontiers' (Finkelstein, 1995: 369). The main criticism of 
the global governance concept is that it does not sufficiently consider the close connection between political and economic structures and processes, and does not provide a sufficient analysis of the nature of global challenges nor the power relations amongst corporate actors (Scherrer and Brand, 2011). Dingwerth and Pattberg (2006) distinguish between two general uses of the global governance concept: first as an analytical concept and second as a political programme. The latter can be expressed as either a normative perspective or as a critical perspective. Scherrer and Brand (2011) add another perspective which is the use of the global governance concept as descriptive category. In this context global governance describes new developments in international relations and stresses the importance of other spatial levels in addition to the national level. The former, analytical perspective focuses on the actual or perceived reality of world politics and the factors which determine new forms of political regulation. Furthermore, it considers the efficiency of mechanisms of interaction at the global level and its impact. Thus, global governance as an analytical concept attempts to explain a structure-process-impact relationship (Mayntz, 2005).

The concept of global governance for the purposes of this study is oriented towards a new 'culture of cooperation' which is based on a multilateral understanding of politics adjusted to democratic principles (Huber, 2008: 57). In this context, it can be interpreted as the initiation of cooperation and coherent action between global organizations towards a specified global problem, where each organization has different resources available and represents different interests. Global governance is not considered to be equal to established forms of governance at the national level where socially binding programmes can be decided and implemented.

For the purposes of this study, the international organizations involved in the dialogue are described as corporate social actors. The actor status of these organizations derives from the expectations of other actors such as governments, individual actors and stakeholders who hold them responsible for their actions (King et al., 2010). As corporate social actors they have a clearly defined relationship with their member organizations. In particular in the case of the IFIs the organizations could be understood as, 'authorized social actors and social artefacts that is, social tools fashioned by founders for specific purposes' (Whetten and Mackey, 2002: 397). However, even though there is a certain dependency relationship with national governments, it does not describe the nature of the organizations within the study per se; rather the focus is on international organizations as 'social actors'. This means that even though they do not share the same structural attributes as human actors they do have functionally equivalent characteristics (King et al, 2010). Social actors can take goal-oriented actions, intervene actively in their environment, act without the consent of their members, and can make intentional decisions and use resources to achieve their goals. Finally, they are also able to 
reflect on their own actions, to learn from experiences and are to some extent accountable for their actions.

However, although there are features which these organizations have in common, they are quite different in terms of the arenas in which they operate, their resources, their bureaucratic structure, their identity and culture and their ability to change and to adapt to environmental changes. So for example, the main arena for the WB is general development policy, for the IFC it is the support of private sector companies, for the IMF it is global financial policy and for the Global Unions it is workers' interests which are paramount. These arenas determine different problem definitions and solutions which are the result of different political beliefs and ideologies.

The bureaucratic structure of an organization includes different elements such as job positions, policies, programmes and procedures and determines the character of an organization which has influence over its agents. In this context different divisions of an organization create, 'fragmented patterns of thought and action' which affect the flow of knowledge and organizational learning (Morgan, 1997: 88). Both the WB and the IMF have strong hierarchical divisions, and the WB also has strong horizontal divisions which limit the free flow of knowledge. As a result, different subunits (Morgan, 1997: 88), 'often operate on the basis of different pictures of the total situation, pursuing subunit goals almost as ends in themselves'. The organizational structure also has an effect on decision making. Decision-making is mainly linked to individual actors, their cognitive limitations and preferences. In order to facilitate coordination among individual actors the different subunits develop programmes of activities or responses regards certain stimuli which facilitate search and selection processes for individual actors. Over time they can lead to a routinization of activities which make organizational learning processes more difficult. Institutionalized policies and programmes and the routinization of activities can hamper the cooperation between organizations and the development of joint positions and policies. This is because routinized activities tend to hinder organizational agents' abilities to see the bigger picture. However, organizational representatives do not only engage in 'routinized' behaviour, but also in tactical and political behaviour which becomes expressed in 'power-struggles, alliance-formation, strategic manoeuvring and 'cut-throat' actions' (Schein, 1977: 64). Those individuals who seek to control organizational decisions and actions can be seen as 'influencers'. Influencers have their own levers of power and their success in influencing and controlling decisions determines the 'configuration of organizational power' (Mintzberg, 1983: 22). Intra-organizational power struggles form an important reality of organizational life, however, the real nature and influence of individual political behaviours within organizations, including the underlying intentions of 
individual actors and the resources these actors have available, are difficult to investigate and reveal for those outside the organization.

Power resources available to corporate social actors include the use of financial and nonfinancial resources, the organizational structure and rules as well as the formal authority, the control of organizational knowledge and the ability to cope with uncertainty which exists within and outside an organization (Morgan, 1997). Differences concerning the distribution of power sources can lead to power asymmetries within and between corporate actors which may cause conflict if more powerful actors decide to exploit or try to influence weaker actors. Power also plays a role with regard to relations and interactions among individual actors, their relations and interactions with a corporate actor as well as with regard to relations and interactions among corporate actors. The paper argues that the dialogue can help to mitigate problems which are interconnected with organizational characteristics such as for example routinization. Furthermore, the dialogue can help to fill 'global governance gaps' such as knowledge and normative gaps (Weiss, 2011) and contribute to balancing out the unequal power relationship among different corporate actors within the system of global governance.

\section{How does the dialogue work?}

The Global Unions have been concerned about the negative impacts of IFI policies on workers for quite some time, but particularly from the 1980s onwards when the IMF and WB began operating within a framework of economic neo-liberalism (Stiglitz, 2008). The origins of the dialogue date back to the 1990s, when the predecessors of the ITUC, the ICFTU (International Confederation of Free Trade Unions) and the WCL (World Confederation of Labour), and some GUFs started to discuss and criticise IFI macroeconomic policies with IFI officials. At the end of the 1990s meetings between the ITUC, the GUFs and the IFIs started to take place on a more regular basis. Around the turn of the millennium, in 2002, the Global Unions and the IFIs finally adopted an agreement concerning a regular and enhanced dialogue and a formalized structure (WB, 2002). This agreement was updated in 2013 by the ITUC, the IMF and the WB. The 2013 framework identifies the ITUC as a 'core trade union interlocutor' at the multilateral level and reaffirms the structure of the dialogue. In addition, it stresses the importance of consultation between the IFIs and the labour unions on, 'labour related issues in individual countries, regionally, or globally with regard to on-going and new projects, programs and policies' (Framework for Dialogue, 2013: 1).

The agreement adopted in 2002 defined three levels of dialogue which influence each other. At the HQ level, there is a dialogue between the headquarters of the ITUC and their affiliates, the 
GUFs the WB, the IFC and the IMF (including organizational leaders, staff in high administrative positions and representatives of member organizations). These meetings include high-level meetings which take place every two years and include a large delegation from the Global Unions as well as a broad representation of staff from the IFIs. High-level meetings normally take place over three days in Washington and focus on an agenda which includes topics which are not specific to any particular sector. The high-level meetings are supported by technical meetings and interim meetings which include smaller delegations of the Global Unions and the IFIs. During technical meetings, which take place several times a year in between high level meetings (over a period of one or two days), the focus is on very specific issues such as pensions or labour market reforms. During interim meetings a relatively small group of trade unionists and IFI representatives regularly follow up the implementation of the commitments made at high-level and technical meetings.

Although not within the scope of this paper, it is worth noting that the second level of the dialogue (sector-level) takes place between individual GUFs - which cover nine major sectors of economic activity in both the public and private sectors ${ }^{\mathrm{i}}$ - and the WB with the objective of establishing an effective exchange of information on WB policies and projects in specific sectors. The third level of the dialogue (at the country level) includes the exchange of information between WB country offices and national trade union organizations and between IMF country mission teams and national trade unions.

\section{A definition of the dialogue}

The HQ-level dialogue may share some of the characteristics of social dialogue, such as for example the focus on long-term gains and the enduring political will of all parties involved to achieve commitments. The HQ-level dialogue also shares some characteristics of lobbying, for example it can be seen as a form of advocacy aimed at changing the general policy approach and paradigm of the IFIs. However, the dialogue also differs in several aspects from 'social dialogue and lobbying and for that reason it requires its own specific definition.

The HQ-level dialogue between the Global Unions and the IFIs can be defined as an institutionalized communication process which takes place on a regular basis. It can be classified as a form of international policy dialogue which takes place between organizations which are active at the global policy level. The organizations involved do not act as social partners and do not negotiate specific agreements. Rather, this form of dialogue serves to exchange views, to develop a better understanding of each other's approaches and to identify possible areas of cooperation. 
From the trade union perspective, the dialogue is also about acquiring policy commitments from the IFIs. The dialogue between the Global Unions and the IFIs is based on the development of a long-term relationship between all the organizations involved and is aimed at creating more trust in the relationships amongst the organizational representatives. The dialogue includes information sharing mainly on a formal level, and to a minor extent, on an informal level. It is not about influencing specific decision-making processes to achieve advantages for an individual organization and its members; it is more holistic.

\section{The organizations involved in the dialogue - the Global Unions and the IFIs}

\section{The Global Unions}

The Global Unions have a very large membership and clearly defined mandates which make them important actors at the international policy level. The ITUC has 315 members and represents the interests of 175 million workers across the world. Their broad membership base and their democratic structures provide the Global Unions with a source of power and legitimacy which clearly distinguishes them from non-governmental organizations (NGOs) and non-profit organizations (NPOs).

Unions remain by far the largest membership organizations in the world and have extensive international coverage, dwarfing non-governmental organizations (NGOs)

...they are also engaged with the impact of globalisation (Croucher and Cotton, 2009: 4).

The Global Unions have a clear and unique set of characteristics, in that they are the, 'only universal and democratically organized movement at world level, with an unequalled capacity for resistance' and, '...the only movement through which millions of workers achieve power through organization' (Gallin, 2002: 250).

Despite this the WB and the IMF do not officially distinguish between trade unions and other civil society actors. On its website, the WB states that it interacts with, 'hundreds of Civil Society Organizations (CSOs) every day throughout the world' but there is no specific mentioning of trade unions or other types of CSOs. The IMF also uses the term in a general way referring to, ' ... business forums, faith-based associations, labour unions, local community groups, non-governmental organizations (NGOs), philanthropic foundations, and think tanks' (IMF, 2016).

By comparison the ITUC considers itself as a, '...countervailing force in the global economy' (ITUC, 2014: 8). It mainly does political work at the global level and through the Economic and Social Policy Department it, ' ... seeks to increase intergovernmental cooperation to ensure that the social dimension of globalization, including decent work and fundamental workers' 
rights, is right at the centre of decision-making within the world's major global and regional institutions' (ITUC website). The work of the ITUC is supported by the nine GUFs, although some GUFs are more heavily involved in the dialogue than others and largely depending on their organizational resources and individual priorities which are determined by their member unions at the national level.

In the broadest sense each GUF is a kind of a 'docking station' for national trade unions (TraubMerz and Eckl, 2007: 5). Many GUFs deal directly with MNEs and try to 'achieve material gains for their members' (Abbott, 2011: 162). In order that the GUFs can do their work effectively, they rely on information from their national affiliates and regional organizations. The GUFs have a broad expertise regards legal and economic issues which arises from their practical experiences of working with and focusing on MNEs, other companies and their networks, International Frameworks Agreements (IFAs) and international trade union campaigns. GUFs aim to regularly 'improve their knowledge of the internal dynamics of large corporations' (TUAC, 2005: 14). This specific knowledge arguably gives the GUFs an initiator role in respect of trade union policy at the global level (Cotton and Gumbrell-McCormick, 2012).

\section{The IFIS}

In contrast to the Global Unions, the International Financial Institutions (IFIs) have become central actors in international politics acting as 'agents of global change' (Carbone, 2007: 180). Both the WBG and the IMF have played an important role in governing the international economy and promoting 'development' since the post-World War II period (Chorev and Babb, 2009). They were founded with the objective of providing global public goods (GPGs) for people across the world and to offer governments the possibility to participate in activities 'that required some separation from domestic politics in order to generate legitimacy and trust' (Martinez-Diaz, 2008: 7). However, since the 1980s the IFIs have mainly been concerned with the, 'coercive diffusion of neoliberal economic policies', amongst their member governments (Torfason and Ingram, 2010: 357).

The IMF has a 'normative' influence on the system of global governance, in that it provides information about certain 'norms' such as 'austerity' and has the, 'hands-on expertise required to establish structures of conformity with those norms' (Ibid., 2010: 357). The WBs' annual flagship report 'Doing Business' still considers labour regulations as obstacles to investment and growth. The latter ranks those countries with the most desirable and 'best' outcomes for businesses as those that have, '...the most business-friendly regulation' (WB, 2013: 2), meaning that countries with a weak regulatory environment (for example Singapore) are ranked 
highest, which clearly contradicts the idea that labour standards need to be enhanced and protected (WB, 2013).

The general objective of the WB is to give financial and technical support to governments of developing countries for public sector projects. In this context, the IBRD (International Bank for Reconstruction and Development) focuses on middle-income countries whereas the IDA (International Development Agency) focuses on the poorest countries worldwide. According to its self-definition the WB is, '...not a Bank in the ordinary sense, but a unique partnership to reduce poverty and support development' (World Bank website, $2018^{\mathrm{ii}}$ ). The Bank describes itself as 'global development cooperative' (World Bank, 2012: 14). Apart from the development approach the 'bank approach' is important in gathering financial resources. The IBRD is active in the global financial markets where it issues bonds and passes its low interest rates on to its borrowers. The WB's stated aim is not to maximize its own profits, however, its operations on the international financial markets suggest a dichotomy of interest in that it is on the one hand a money lender and on the other hand a 'development agency' which, 'wants to reduce poverty' (WB01 official, 2008). This dichotomy determines the organizational values which are, on the one hand, market and economy oriented, and on the other hand focused on social development. Apart from its material resources the IBRD and the IDA have more than 10,000 members of staff around the world. Two-thirds of them work at WB headquarters and one-third in the more than 120 country offices.

The IMF promotes international monetary cooperation and exchange stability (IMF, 2011). In comparison to the WB, the IMF does not emphasize development even though it does promote 'economic development' indirectly through its financial support for countries, when such countries face difficulties with their balance of payments or in the context of financial crises (IEO, 2008). Hence, the IMF is not troubled by a dichotomy of approaches with regard to its mission. However, in trying to fulfil its mandate potential conflicts do arise in respect of its dual roles as 'global watchdog' and 'trusted advisor' (IEO, 2013: 11).

In terms of fulfilling their missions the IFIs and the GUFs have over the course of time developed specific knowledge, organizational routines, programmes and strategies. However, knowledge is developed and based on certain ideological paradigms. The IFIs still follow a neoliberal agenda which has largely been shaped by the 'Washington Consensus', that is policies recommended by the IFIs and the US Treasury. During the 1980s and early 1990s these policies relied very much on 'market fundamentalism' and 'entailed a much more circumscribed role for the state' (Stiglitz, 2008: 46). Despite the 2008 economic crisis the IFIs still follow a paradigm based on free-market orthodoxy including the promotion of deregulation 
and privatization. In comparison, the Global Unions follow a paradigm which is based on global social justice in line with ILO guidelines and labour standards and broader human and labour rights principles.

\section{The dialogue: successes and challenges}

Cooperation and successful communication within the dialogue depends to a large extent on the attitudes, opinions and mutual perceptions of the individual actors involved. Perceptions and opinions of individual actors are shaped to a large extent by the organizations which they represent and by the predominant organizational paradigm and values. In the case of the Global Unions the universally recognized values and principles comprise solidarity, democracy and equality (ITUC, 2010). The organizational paradigm of the Global Unions is oriented towards global welfare and a more equal distribution of global wealth. In contrast, the paradigm of the IFIs is based on capitalism and the promotion of economic development and international monetary cooperation. The IFIs also have explicit codes of conduct for staff which aim to guide the behavior of individual actors.

Despite differences of perception, the interview findings and observations of the high-level meetings suggest that there is a wide agreement between the different organizational representatives involved, that all levels of the dialogue are essential and important. During the most recent high-level meeting in Washington in 2017, the ITUC Secretary-general described the WB as an, 'increasingly robust partner' and a WB representative stated that the cooperation with the unions is 'very productive' and that there is a move towards 'common views as multilateral organizations' (Minutes high-level meetings, 2017). However, these 'positive' statements are not necessarily reflected in respective individual and corporate behaviours and actions.

For the ITUC, the importance of the dialogue with the IFIs is conditioned by its perspective that the dialogue is a 'strategic instrument' which they see as a mechanism to change IFIs policies. According to the director of the ITUC/Global Unions office, the Global Unions engage in the dialogue with, 'very specific objectives of changing policy' and not 'for the purpose of simply discussing each other's point of view' (Interview ITUC02, 2008). The objective of achieving change in IFI policies has been a consistent aim of ITUC and GUF representatives who have been actively involved in the dialogue. The interviews revealed several factors which are closely related to the achievement of organizational change within the IFIs, some of which can be actively influenced by trade unions and their members whilst others cannot. 
One factor which is considered to be important for the trade unions is time. It is widely acknowledged that a change of policy within the IFIs cannot be achieved in the short-term. However, according to an official of Education International (EI) in 2008 the dialogue, 'can bring changes in the long term'. Time is also influential in respect of the different phases of the dialogue. There are times when progress is made and other times, 'when things move more slowly' (ITUC01 official, 2008). A second factor which the trade unions consider as relevant with regard to the achievement of change is the persistence of their demands. Independently from the immediate feedback that trade unions receive from IFI staff and from the output they achieve in the short- and medium-term, it is also important for the unions to have a constant voice and presence. In order to give a clear message to the WB and the IMF that unions cannot be ignored they need to be actively engaged in following up the policy developments of the IFIs and have their voices heard within the high-level meetings with the IFIs. As a PSI (Public Service International) official put it, '...look we are here, you've got to talk to us'.

While the unions have little influence over the time required to make changes in IFI policies, their persistence can have an effective influence and this depends on the persistence of individual actors and both collective and individual resources. The former include the resources trade unions have available to promote certain issues and the priorities which have been set through the unions' democratic decision-making processes. On the individual level, an important factor is the positive individual attitude towards the dialogue, the ability to deal with the setbacks resulting from bilateral communication with IFI staff and, making the relationship work. For example, according to an official from the Building and Wood Workers International (BWI), the organization adopts a 'very dogmatic' approach when dealing with staff from the WB procurement department and 'nurtures that relationship' (BWI02 official, 2017). In this regard the focus is on getting the attention from governments, contractors and the WB and achieving trade union recognition with the contracting companies.

A third factor which plays into the promotion of organizational change and which has been mentioned by trade unionists is leadership within the IFIs (IG Metall official, 2008). Leadership is connected to the attitudes of specific individuals and the political will to initiate and promote change. Due to the fact that under normal circumstances the presidency of the WB is only for a five year period, it can be argued that the space the WB offers for 'reformers' and their ideas is to some extent cyclically shaped and dependent on the attitude of the WB president. Thus, a president who is more open to the idea of organizational reforms and responsive to trade union concerns creates a window of opportunity for the Global Unions in that their concerns and proposals are more likely to be heard. For example, James Wolfensohn who was the president of the Bank in 1995 pushed for an expansion of the development dialogue with civil society for 
ten years and initiated the idea of establishing secondments for trade unionists to spend time at the WB. This was an important step to foster the exchange between WB staff and trade unionists, even though it only took place on a very limited scale (PSI official, 2008). In contrast to Wolfensohn, both Presidents Paul Wolfowitz (2005-2007) and Robert B. Zoellick (20072012) did not have much time for trade unions (ITUC04 official, 2009; ITUC02 official, 2011). There is a similar situation at the IMF where some union officials feel that, 'the personal openness and desire to collaborate' with unions from the side of the current managing director has diminished in recent years (ITUC02 official, 2015).

Representatives of the IFIs nevertheless see the dialogue with the Global Unions as important and many of them express positive opinions in this regard, though for them it is not about achieving change. For the IFIs the dialogue was and is primarily about legitimizing their own policies with civil society in general and in seeing trade unions as important stakeholders of global civil society in particular. All IFI representatives who were interviewed perceived the Global Unions as large and democratic membership organizations (WB01 official, 2008; IMF01 official, 2008). They relate these organizational characteristics with a broader legitimacy related to trade unions in general and perceive the organizations as representing, 'people with a strong interest in the economy, economic policy and economic outcomes' (IMF01 official, 2008). As a result, IFI representatives, at least in terms of their rhetoric, are supportive of the dialogue at all its different levels including the national level where the "voices of trade unions are essential in the country's economic dialogue' (Ibid., 2008). During the highlevel meeting in 2017 one speaker from the IMF noted that it is critical to have the dialogue, as the meetings provide an opportunity to discuss issues such as economic recovery, job creation and labour market reforms (Minutes high-level meetings, 2017).

With regard to communication processes within the dialogue it can be argued that there is not always a direct correlation between individual attitudes and communication, particularly with regard to long-term communication. In other words, positive individual attitudes do not necessarily lead to better communication and negative individual attitudes do not necessarily undermine communication between individual actors over the long term. Regards the WB for example, a former Executive Director stated that there has been a general, 'openness towards trade unions which is not tactical, but serious' (WB05 official, 2009). However, this general organizational openness which has been translated into more individual willingness to communicate with trade unions, does not for example, sufficiently promote labour issues as cross-departmental issues (Ibid., 2009). Communication on labour issues seems to be mainly limited to specific units such as the former Social Protection and Labour (SP\&L) unit of the WB and its staff. However, even here the action of individuals sometimes had a negative effect. 
For example, a former staff member of the SP\&L unit showed a very positive attitude towards the dialogue during the interview, arguing in 2008 that in his opinion the WB has a, "very productive dialogue with trade unions and that generally speaking the dialogue with the trade unions is one of the best structured dialogues the WB has with civil society organizations' (WB02 official, 2008). However, according to union officials his positive attitude, did not translate into action or the improvement of communication within the dialogue. In fact, the opposite was the case, according to one ITUC official, until he left his post in 2011, the same SP\&L staff member made the exchange of information more complicated and tended to delay responses to requests from trade unionists. In 2014 however, the SP\&L unit was integrated into the WB's 'jobs cross-cutting solution area' and according to the same ITUC official things have since improved, he states that the WB's jobs group, '... has been quite keen on working more closely' with the trade unions (ITUC02 official, 2015).

However, some IFI officials define the use and perceptions of economics and economic research as a major difference between the Global Unions and the IFIs. According to a WB official, the WB places more emphasis and use of economics as, 'theoretical research', even though there are practical implications at the country level where it is often used for policy advice. The same WB official stated that trade unionists generally have, 'more of a practical approach' even though unions undertake research activities in terms of economic forecasts (WB01 official, 2008). A former WB official interviewed in 2017, however, is quite critical about the use of economic methodology at the bank. The organisation is a 'kingdom of economists', which tends to focus on data and conclusions and fails to consider the processes on which actual outcomes depend (Interview F-WB, 2017).

The fact that IFI staff assume that the unions adopt a more 'practical' approach can be seen as a kind of stereotyping and is closely related to their resources (staff). IFI staff often assume that all trade union organizations follow a more practical approach, because they mainly see their activities at the national level, above all their activities around collective bargaining. However, there is a growing awareness amongst IFI staff that trade unions also undertake extensive theoretical research and forecasts through joint organizations such as TUAC and the European Trade Union Institute (ETUI). During the high-level meeting in 2009, for example, the General Secretary of TUAC had already provided the IFIs with an economic forecast warning the IFIs that the economic crisis was likely to cause a dramatic increase in European unemployment in the same year (Minutes high-level meetings, 2009). This was largely ignored by the IMF at that time as they were still not focusing on the employment issue. 
Furthermore, the interviews revealed that the dialogue partners have different expectations with regards to information exchange. On the one hand trade unionists usually have well defined expectations which are linked to their organizational objectives and pursued through the dialogue. On the other hand, the expectations of IFI representatives are poorly defined or not defined at all. IFI representatives state that over time the dialogue, particularly the HQ-level dialogue, has moved away from an, 'ideological debate to a more constructive one' (WB, 2006: 1-2). This new 'constructiveness', however, seems to be little related to a better provision of information from IFI staff to trade unionists. On the contrary, Global Union representatives regularly ask for more information about planned IFI projects and programmes which concern workers with enough time for them to process and take a position on them (ITUC02 official, 2008). For that reason, the constructiveness of the dialogue seems to be, as far as IFI staff are concerned, more related to the exchange of arguments during meetings than to the provision of information in between such meetings. As far as the ITUC are concerned (ITUC02 official, 2015), the exchange of information and consultation on projects from the side of IFIs has not really improved, despite the amendments made to the agreement of the dialogue in 2013.

During the high-level meetings the exchange of information between the IFI and Global Union representatives is limited due to the nature of the meetings themselves. In a relatively short period of three days organizational representatives discuss a broad range of topics. In order to facilitate a mutual understanding this kind of meeting is translated into five languages and trade unionists have an allocated speaking time of just three minutes (Minutes high-level meeting, 2009). The time pressure and the amount of different issues to discuss often only allow a verbal expression of individual opinions and organizational positions rather than a more profound exchange of information and discussion. However, the high-level meetings are important in terms of a mutual confirmation of joint engagement in the dialogue. It also provides interlocutors, particularly the trade unions, with the possibility to raise awareness for specific issues such as for example the importance of inclusive growth and a living wage and, to repeat their message that collective bargaining can and should play a major role in reducing income inequality and, to define and initiate new areas of joint cooperation which can be further developed during smaller meetings. The success of the dialogue is very dependent on the individual actors involved on both sides, although this is 'not how it should work' according to the ITUC (ITUC02 official, 2015). In order to develop a 'sustainable' dialogue over the long term which is independent from the engagement of individual actors, the ITUC officials argue that they need to see a greater commitment to the dialogue from a larger number of departments in the IFIs, they suggest this could for example be achieved by providing staff with incentives to consult with trade unions on a more regular basis. 


\section{Discussion and conclusion}

The article contributes to the research on the Global Unions and transnational industrial relations focusing on the relationship between the international financial organizations (IFIs) and the Global Unions. The dialogue examined in the article can be considered as a tool which helps trade unions to exercise their functions of articulation and participation at the global level allowing them to try to promote a global system of global social regulation. Until now there has been no systematic research undertaken on this form of dialogue. Hence, the contribution to knowledge of this article is twofold. First, the paper introduces a form of dialogue which has not been considered in the literature so far and attempts to point out some of the factors which promote its success and others which are perceived as challenging by the interlocutors involved in the dialogue. Secondly, on a theoretical level the paper makes an attempt to interlink organizational theories with the global governance concept in order to strengthen its analytical dimension. In this regard some of the organizational characteristics of the corporate actors which have an impact on perceptions and attitudes of individual organizational representatives have been highlighted. This includes for example the bureaucratic structure and the dominating organizational paradigm. The bureaucratic structure includes different elements such as positions, policies and programmes which determine the character and the degree of routinization of activities in organizations and which has influence over its agents in terms of their ability to see the bigger picture (Meyer and Rowan, 1977).

The analysis suggests that there has been a cultural shift in the IFIs with regard to their understanding of engagement with civil society organizations since the dialogue was formally established in 2002 and there appears to have been a general increase in awareness amongst IFI staff with regard to labour issues since that time. However, the relationships between the Global Unions and the IFIs are very complex. On the one hand, the increase in awareness amongst IFI staff does not necessarily mean that IFI staffs regularly engage or want to engage with trade unions. This depends to a great extent on individual attitudes and personalities which, in turn, are shaped to a large extent by the organizational paradigm, the policy approaches of the organization within which individual actors work and the organizational expectations towards them.

Despite their commitment to the dialogue in the protocol from 2002 and 2013, so far the IFIs have put no incentives or polices for staff in place which encourage individual actors to communicate with trade unions on a more regular basis. The lack of such policies leads to a rather inconsistent provision of information from IFI staff and their departments to trade unions. For that reason, at the high-level meetings trade union representatives consistently argue that 
they should be properly consulted regarding the development of new programmes and the conditions attached to IFI loans on issues which concern labour before they are implemented. The Global Unions argue that is essential that their expertise contribute to the development of such programmes and, that the IFIs should avoid the all too many cases where Global Union representatives only found out about new IFI projects which concern their sectoral work when details were published in the media. However, the dialogue can help to develop a better mutual understanding among individual actors and their perceptions regards global problems and as such the development of joint perspectives among the different actors through dialogue is arguably a first important step and precondition for further cooperation regards the establishment of social policies at global level.

As a strategic instrument the dialogue can be considered as a tool through which the Global Unions can have an influence over the current global logic; at least in terms of partly transforming this logic. However, this process is very slow and unless the dialogue is seen to provide concrete results for their national affiliates, Global Union organizations often find it difficult to ensure sufficient and continuing support from their membership. In this context, it is important for trade unions to make sure that the IFI's positive sounding rhetoric is translated into action and to confront the IFIs with the continuing and stark contradictions between the policies they promote and the practical outcomes they create which are based on factual evidence.

Overall the current situation contributes to the maintenance of the existing power asymmetries between the corporate actors within the dialogue, because one of the power resources which trade unions have, that is the mobilization of their members, is hardly available in this context. However, trade unions represent the largest membership organizations in the world and they are important stakeholders of global civil society whose legitimacy is based on democratically elected leadership and democratic procedures. Their legitimacy and their expert knowledge in the field of labour market issues defines them as an important balancing force in the system of global economic governance. Since the international economic and financial crisis trade unionists have placed even more attention to the idea of economic democracy and the idea of trying to 'create new links between different levels of regulation and different issues on the regulatory agenda' (Hyman and Gumbrell-McCormick, 2010: 371). This focus may yet have an impact on the shaping of the agendas in the Global Union organizations and their affiliated unions and lead to a further strengthening of the dialogue as a strategic instrument for trade unions. 


\section{References}

Abbott, K. (2011) 'Theorising International Trade Unionism', Global Labour Journal 2, 3:160-179.

Abouharb, M.R. and Cingranelli, D. (2008) 'Human Rights and Structural Adjustment', Cambridge, New York, Melbourne, Madrid, Cape Town, singapore, Sao Paulo, Delhi: Cambridge University Press.

Aidt, T. and Tzannatos, Z. (2002) Unions and Collective Bargaining: Economic Effects in a Global Environment, Washington D.C: World Bank.

Argote, L. and Miron-Spektor, E. (2011) 'Organizational Learning: From Experience to Knowledge', Organization Science 22, 5: 1123-37.

Barnett, M. and Finnemore, M. (2004) Rules for the World: International Organizations in Global Politics, Ithaca and London: Cornell University Press.

Behrens, M. and Reichwein, A. (2007) 'Global Governance', in Benz, A. et al., (eds.) Handbuch Governance: Theoretische Grundlagen und empirische Anwendungsfelder. Wiesbaden: VS Verlag: 311-24.

Braun, V. and Clarke, V. (2006) 'Using thematic analysis in psychology' Qualitative Research in Psychology, 3, 2: 77-101.

Brown, A.D. and Starkey, K. (2000) 'Organizational Identity and Learning: A Psychodynamic Perspektive' The Academy of Management Review, 25, 1: 102-20.

Carbone, M. (2007) Supporting or Resisting Global Public Goods? The Policy Dimension of a Contested Concept, Global Governance 13, 2: 179-98.

Chorev, N. and Babb, S. (2009) 'The crisis of neoliberalism and the future of international institutions: A comparison of the IMF and the WTO', Theory and Society 38, 5: 45984.

Clarke, V. and Braun, V. (2017) 'Thematic analysis' The Journal of Positive Psychology, 12, 3: 297-298.

Croucher, R. and Cotton, E. (2009) Global Unions, Global Business. Global Union Federations and International Business, London: Middlesex University Press.

Cotton, E. and Gumbrell-McCormick, R. (2012) Global Unions as imperfect multilateral organizations: An international relations perspective, Economic and Industrial Democracy 33, 4: 707-28.

Dingwerth, K. and Pattberg, P. (2006) Global Governance as a Perspective on World Politics, Global Governance: A Review of Multilateralism and International Organizations 12, 2: 185-203. 
Easterly, W. (2005) 'What did structural adjustment adjust?: The association of policies and grwoth with repeated IMF and World Bank adjustment loans', Journal of Development Economics 76, 1: 1-22.

Finkelstein, L.S. (1995) What Is Global Governance?. Global Governance 1, 3: 367-72.

Flick, U. (2014) An Introduction to Qualitative Research, 5th ed, Los Angeles, London, New Delhi, Singapore, Washington DC: SAGE.

Framework for Dialogue (2013) Framework for Dialogue between the International Trade Union Confederation (ITUC), International Monetary Fund (IMF) and WB. 12 February 2013.

Gallin, D. (2002) Labour as global social force. Past divisions and new tasks. In Harrod, J. and O'Brien, R. eds. Global Unions? Theories and strategies of organized labour in the global political economy. London, New York: Routledge: 235-50.

Hepple, B. (2005) Labour Laws and Global Trade, Oxford: Hart Publishing.

Herod, A. and Aguiar, L.M. (2006) 'Introduction: Cleaners and the Dirty Work of NeoLiberalism', Antipode, 38, 3: 425-434

Huber, J.F. (2008) Global Governance - Lösungsweg oder Utopie? Strategien, Kritik und Ausblick, in Gruber, P.C. (ed.), Nachhaltige Entwicklung und Global Governance. Verantwortung. Macht. Politik, Opladen, Farmington Hills: Barbara Budrich: 55-69.

Hyman, R. and Gumbrell-McCormick, R. (2010) 'Trade unions and the crisis: a lost opportunity?', Socio-economic review, 8 2: 364-72.

IEO (2013) The Role of the IMF as Trusted Advisor, [pdf] <http://www.ieoimf.org/ieo/pages/CompletedEvaluation157.aspx > [Accessed 7 May 2017]

IEO (2008): Governance of the IMF. An Evaluation. Independent Evaluation Office of the International Monetary Fund. http://www.ieoimf.org/ieo/pages/CompletedEvaluation110.aspx [Accessed 7 May 2017]

IMF (2016) The IMF and Civil Society Organizations, Factsheet April 2013. <http://www.imf.org/external/np/exr/facts/civ.htm> [Accessed 1 June 2017]

IMF (2011) Articles of Agreement, [online]

<http://www.imf.org/external/pubs/ft/aa/index.htm> [Accessed 7 May 2017]

ITUC (2014) Constitution and Standing Orders, As amended by the 3rd Congress (Berlin, Germany, May 2014). [pdf] <https://www.ituc-csi.org/IMG/pdf/ituc_constitution.pdf> [Accessed 25 May 2017]

Jaumotte, F. And Buitron, C.O. (2015) 'Inequality and Labour Market Institutions', IMF Discussion Note 15/14.

Katz, L.F. and Krueger, A.B. (2016) The Rise and Nature of Alternative Work Arrangements in the United States, 1995-2015, Working paper 603, 13th September, New Jersey: Princeton University, http://arks.princeton.edu/ark:/88435/dsp01zs25xb933 
Keffer, J.M. and Hill, R.P. (1997) 'An Ethical Approach to Lobbying Activities of Businesses in the United States', Journal of Business Ethics, 16, 12/13:1371-79.

King, B.G., Felin, T. and Whetten, D.A. (2010) 'Finding the Organization in Organizational Theory: A Meta-Theory of the Organization as a Social Actor', Organization Science 21, 1: 290-305.

Koch-Baumgarten, S. (2006) 'Globale Gewerkschaften und Industrielle Beziehungen in der Global Governance', Industrielle Beziehungen, 3:205-222.

Marginson, P. (2016): 'Governing Work and Employment Relations in an Internationalized Economy: The Institutional Challenge', Industrial and Labour Relations Review, 69, 5: 1033-1055.

Martinez-Diaz, L. (2008) Executive Boards in International Organizations: Lessons for Strengthening IMF Governance. Background Paper. Independent Evaluation Office of the International Monetary Fund. [pdf] <http://www.ieoimf.org/ieo/files/completedevaluations/05212008BP08_08.pdf > [Accessed 5 May 2017]

Mayntz, R. (2005) 'Embedded Theorizing. Perspectives on Globalization and Global Governance', MPIfG Discussion Paper 05/14, Cologne.

Meyer, J.W., Drori, S.G. and Hwang, H. (2006) 'World Society and the Proliferation of Formal Organizations' in Drori, S.G. et al., (eds.) Globalization and Organization, Oxford: University Press: 25-49.

Meyer, J.W. and Rowan, B. (1977): 'Institutionalized organizations: formal structure as myth and ceremony', American Journal of Sociology, 82, 3: 340-363.

Mintzberg, H. (1983) Power In and Around Organizations. Englewood Cliffs: Prentice-Hall.

Morgan, G. (1997) Images of Organization. Thousand Oaks, London, New Delhi: SAGE.

Nuscheler, F. (2002) 'Global Governance', in Ferdowsi, M.A. (ed.) Internationale Politik im 21. Jahrhundert, München: Wilhelm Fink Verlag: 71-86.

Schein, V.E. (1977): 'Individual Power and Political Behaviours in Organizations: An Inadequately Explored Reality', Academy of Management Review, 2, 1: 64-72.

Scherrer, C. and Brand, U. (2011) Global Governance: konkurrierende Formen und Inhalte globaler Regulierung. [online] Bonn: Friedrich-Ebert-Stiftung. <http://library.fes.de/pdf-files/akademie/online/50334-2011.pdf> [Accessed 8 April 2017]

Sengenberger, W. (2005) Globalization and Social Progress: The Role and Impact of International Labour Standards, Bonn: Friedrich-Ebert-Stiftung.

Stiglitz, J. E. (2008) 'Is There a Post-Washington Consensus Consensus?', in Serra, N. and Stiglitz, J.E. (eds.) The Washington Consensus Reconsidered: Towards a new global governance, Oxford: Oxford University Press: 41-56. 
Torfason, M.T. and Ingram, P. (2010) 'The Global Rise of Democracy: A Network Account', American Sociological Review, 75, 3: 355-76.

Traub-Merz, R. and Eckl, J. (2007) International Trade Union Movement: Mergers and Contradictions. FES International Trade Union Cooperation. <http://library.fes.de/pdffiles/iez/04589.pdf> [Accessed 26 April 2017]

TUAC (2005) Workers' Voice in Corporate Governance - A Trade Union Perspective. Global Unions Discussion Paper. [pdf] <https://members.tuac.org/en/public/edocs/00/00/01/0E/document_doc.phtml> [Accessed 22 April 2017]

Turner, L. (2004) 'Why Revitalize? Labour's Urgent Mission in a Contested Global Economy', in Frege, C. and Kelly, J. (eds.) Varieties of Unionism. Strategies for Union Revitalization in a Globalizing Economy, Oxford, New York: Oxford University Press.

Tussie, D. and Riggirozzi, M.P. (2001) 'Pressing ahead with new procedures for old machinery: Global governance and civil society', in Rittberger, V. (ed.) Global Governance and the United Nations System, Tokyo, New York, Paris: United Nations University Press: 15880 .

Weiss, G.T. (2011): Thinking about Global Governance: Why People and Ideas Matter, London and New York: Routledge.

White, A. (2006) Making a World of Difference. Global Unions at Work. Brussels: IFJ.

Whetten, D.A. and Mackey, A. (2002) 'A Social Actor Conception of Organizational Identity and Its Implications for the Study of Organizational Reputation', Business \& Society, 41, 4: 393-414.

WB (2013) Doing Business 2013. Smarter Regulations for Small and Medium-Size Enterprises. Comparing Business Regulations for Domestic Firms in 185 Economies. <http://www.doingbusiness.org/reports/global-reports/doing-business-2013> [Accessed 20 May 2017]

WB (2012) Annual Report 2012.

$<$ http://siteresources.worldbank.org/EXTANNREP2012/Resources/87844081346247445238/AnnualReport2012_En.pdf> [Accessed 5 May 2017]

WB (2007) Joint Background Paper: Review of Five Years of Structured Dialogue between the International Trade Union Movement and the International Financial Institutions December. <http://siteresources.worldbank.org/INTLM/Resources/GUIFI_Dialogue_12-07.pdf> [Accessed 12 May 2017]

WB (2006) JointReport on Meetings between the International Trade Union Movement (Global Unions and WCL) and the IMF and WB 11-13 December, Washington D.C.. <http://go.worldbank.org/WTUVC6C1H> [Accessed 18 May 2017]

WB (2002) JointReport on Meetings between the International Trade Union Movement (Global Unions and WCL) and the IMF and WB 21-23 October 2002, Washington D.C.. <http://go.worldbank.org/WTUVC6C1H0> [Accessed 18 May 2017] 
' The nine GUFs are: UNI (Union Network International for retail and commerce workers); the ITF (International Transport Federation); El (Education International); IndustriALL (metal workers, chemists, textiles); IUF (hospitality, food, agriculture); IJF (International Journalists Federation); BWI (Building and Wood Workers' International); PSI (Public Sector International); IAEA (International Arts and Entertainment).

ii Source: World Bank, http://www.worldbank.org/en/about/what-we-do [Accessed 15 January 2018] 